Article

\title{
Informal Disaster Governance
}

\author{
Patrizia Isabelle Duda ${ }^{1,2}$, llan Kelman ${ }^{1,2,3, *}$ and Navonel Glick ${ }^{1}$ \\ ${ }^{1}$ Institute for Risk and Disaster Reduction, University College London, London, WC1E 6BT, UK; \\ E-Mails: patrizia.duda.15@ucl.ac.uk (P.I.D.), ilan_kelman@hotmail.com (I.K.), navonel@gmail.com (N.G.) \\ 2 University of Agder, 4604 Kristiansand, Norway \\ ${ }^{3}$ Institute for Global Health, University College London, London, WC1E 6BT, UK \\ * Corresponding author
}

Submitted: 30 March 2020 | Accepted: 15 May 2020 | Published: 10 December 2020

\begin{abstract}
Scholars and practitioners are increasingly questioning formal disaster governance (FDG) approaches as being too rigid, slow, and command-and-control driven. Too often, local realities and non-formal influences are sidelined or ignored to the extent that disaster governance can be harmed through the efforts to impose formal and/or political structures. A contrasting narrative emphasises so-called bottom-up, local, and/or participatory approaches which this article proposes to encapsulate as Informal Disaster Governance (IDG). This article theorises IDG and situates it within the long-standing albeit limited literature on the topic, paying particular attention to the literature's failure to properly define informal disaster risk reduction and response efforts, to conceptualise their far-reaching extent and consequences, and to consider their 'dark sides.' By presenting IDG as a framework, this article restores the conceptual importance and balance of IDG vis-à-vis FDG, paving the way for a better understanding of the 'complete' picture of disaster governance. This framework is then considered in a location where IDG might be expected to be more powerful or obvious, namely in a smaller, more isolated, and tightly knit community, characteristics which are stereotypically used to describe island locations. Thus, Svalbard in the Arctic has been chosen as a case study, including its handling of the 2020 Covid-19 pandemic, to explore the merits and challenges with shifting the politics of disaster governance towards IDG.
\end{abstract}

\section{Keywords}

Arctic; climate change; disaster governance; disaster risk reduction; policy change

\section{Issue}

This article is part of the issue "The Politics of Disaster Governance" edited by Dorothea Hilhorst (Erasmus University Rotterdam, The Netherlands), Kees Boersma (Vrije Universiteit Amsterdam, The Netherlands) and Emmanuel Raju (University of Copenhagen, Denmark).

(C) 2020 by the authors; licensee Cogitatio (Lisbon, Portugal). This article is licensed under a Creative Commons Attribution 4.0 International License (CC BY).

\section{Introduction}

Over the past century, societies have devised vast formal disaster governance (FDG) mechanisms. Yet, when vulnerabilities and risks become disasters, governmental and other formal institutions mandated with disaster risk reduction and response (DRR/R) show limitations. Scholars critiquing FDG attribute these shortcomings to, amongst others, the lack of knowledge, incentives, coordination mechanisms, or flexibility, as well as focusing on infrastructural and technocratic solutions over engaging with existing local resources, including knowl- edge, wisdom, learning, contextual understanding, incentives, people power, and other requirements that FDG cannot or does not provide (Boin, 2009; Lagadec, 1997; Perrow, 2011; Roasa, 2013; Robin, Chazal, Acuto, \& Carrero, 2019). As a specific example, Marchezini (2015) suggests that governmental FDG might sometimes focus on saving individual lives without linking this approach to wider social needs.

In the absence of (effective) FDG, including when climate change continues to be separated from $D R R / R$ by authors such as Grove (2014), successful DRR/R often depends on informal actors and networks (Boersma 
et al., 2019; Carrero et al., 2019; Fritz \& Mathewson, 1957; Rose \& Chmutina, in press) and their "urgently needed tools for knowledge and action" (Fawaz, 2017, p. 101). Such informal DRR/R shifts action away from the government to ordinary people who, often without disaster-related training, devise informal approachese.g., by improvising new or repurposing old informal networks - to supply the much-needed aid normally expected of FDG. Examples of actions are building barriers against hazards, evacuating residents, providing food, water, medical assistance, and emotional support, and leading local clean-up, rebuilding, and relocation efforts (Barenstein \& Trachsel, 2012; Carrero et al., 2019; McFarlane, 2012; Parthasarathy, 2015; Roasa, 2013; Whittaker, McLennan, \& Handmer, 2015). Disaster-affected populations are not only the first to respond to disasters-recently termed zero-order responders (Briones, Vachon, \& Glantz, 2019)-but they also often go beyond their perceived responsibilities to make up for institutional shortcomings (Edwards, 2009; Lavell \& Maskrey, 2014; Maskrey, 2011; Stallings \& Quarantelli, 1985). Accordingly, informal DRR/R activities may encompass long-term development or political and diplomatic agendas that sometimes are opposed to, or bypass, governments (Ide, 2020). As their activities, including by some of the most vulnerable populations, may result in the difference between success and failure of a community's DRR/R (Barenstein \& Trachsel, 2012; Roasa, 2013), informal DRR/R actors may become a powerful (counter-)force creating de facto 'new realities' in ways unanticipated and/or undesired by FDG actors.

Informal human agency, a prevalent theme across many academic disciplines, has been discussed in earlier and recent disaster science, predominantly from the perspectives of intra- and interorganisational informality or as a volunteering/emerging practice by informal actors. Over time, and as informality theoretically became increasingly acceptable with the 'governance turn' in the 1990s, a variety of perspectives and terms related to informal forms of DRR/R developed, even when drawing on much earlier literature. These include self-organisation, convergence, volunteerism, and emergence. Recent additions are multilevel/vertical/horizontal/adaptive/collective/collaborative/decentralised/ local/shadow/networked/grassroots/bottom-up/participatory/community-based DRR/R, disaster governance, or disaster networks. In practice, in an environment which views $D R R / R$ as the responsibility of formal organisations (e.g., governmental and non-governmental disaster management agencies and emergency services), informal DRR/R actors still tend to be ignored, managed, bypassed, or ousted by FDG actors once they are on the scene (Wolbers, Ferguson, Groenewegen, Mulder, \& Boersma, 2016).

Notwithstanding the breadth of references acknowledging the importance of, and bringing important insights to, the complexities of informal DRR/R, knowledge on informality in disasters can remain superficial, lack conceptual discussions and incompletely address practical considerations. Its wider and especially political implications are rarely examined by aforementioned functionalist critiques of FDG and their explanations of informal DRR/R. Consequently, informal actors are derogatorily seen as little more than 'volunteers.' Where informal $D R R / R$ is seen as a viable alternative, this is often limited to equally functional characteristics such as ability to respond faster and more flexibly than FDG actors. This raises doubts as to whether scholars dealing with informal DRR/R have truly detached from these traditional dichotomies, especially when their analyses often lead to the question of how to improve FDG by 'managing' these efforts, so that these will not hinder formal efforts-whereas the logical consideration should perhaps be how to capitalise on informality as an asset, and how FDG could 'serve' capable communities in disasters rather than manage their efforts (Ogie \& Pradhan, 2019). Perhaps these accounts offer more insights on how the involvement of informal actors in disasters is, and has been, imagined and managed by FDG rather than considering them as an integral part of disaster governance per se.

Thus, the theoretical contribution of this article lies in stepping back and examining more fully the meanings and implications of informal DRR/R. In the next section, after a definitional discussion, we discuss the DRR/R literature's limitations on informal $D R R / R$ by focusing on three major gaps, the failures to: define informal $D R R / R$ (Section 2.2); treat it as more than volunteerism, and to acknowledge the political dimension and clout of informal DRR/R (Section 2.3); and discuss its 'dark sides' (Section 2.4). To ground the above, we use the Arctic archipelago of Svalbard and the ongoing Covid-19 pandemic as an empirical case study. We conclude by suggesting the concept of 'informal disaster governance' (IDG) as a broader framework to comprehensively encompass informality in DRR/R.

\section{Gaps in Understanding Informality in DRR/R}

\subsection{Defining Disaster-Related Governance}

Disaster risk reduction (DRR) refers to policies, actions, and activities aimed at understanding and addressing the root causes of disasters (Hewitt, 1983; Lewis, 1999; Wisner, Blaikie, Cannon, \& Davis, 2004), with examples of phrases used being mitigation, prevention, preparedness, preparation, planning, readiness, and capacity building. Actions during and after a disaster-such as emergency management, rescue, response, recovery, and reconstruction-are not explicitly part of DRR, although DRR should be part of them (Cuny, 1994). Thus, the idea of DRR/R helps to connect all aspects of dealing with disasters: before, during, after, and their links and feedbacks. While the final ' $R$ ' is ostensibly used to mean 'response,' just as DRR implies the slew of words listed above, $\mathrm{R}$ implies the various other actions and activities 
not encompassed by DRR. Research, policy, and practice use various other phrases in different ways, such as disaster risk management and disaster risk reduction and management. The key is to recognise the diversity of vocabulary which exists, but to select a shorthand for the wide range of activities referred to, for which we use DRR/R.

In the context of DRR/R governance, typically if ambiguously described as 'disaster governance' or 'disaster risk governance' (even though these phrases are not synonymous), 'governance' means the rules, regulations, norms, systems, and institutions directing, defining, guiding, monitoring, and implementing (i.e., governing) DRR/R (Peters \& Pierre, 1998; Rosenau \& Czempiel, 1992). Government is one such system and institution, which is formal in terms of having a specific structure, form, and individuals identified with the institution. Formality implies some fashion or mode of specificity which can be demarcated and systemised, with the possibility of emulation or repetition, hence FDG.

Emphasising historical roots, some scholars point to formal disaster institutions' outdated design as the source of fundamental challenges and inefficiencies within DRR/R (Kirschenbaum, 2004; Quarantelli, Lagadec, $\&$ Boin, 2007). Despite changes and advances in how disasters are tackled, the baseline structures and forms of today's formal disaster-related institutions were devised more than a century ago to fit the risks and needs of the perceived rising complexities of the industrialisation era (Kirschenbaum, 2004). The elicited response came in the form of centralised, hierarchical, command-andcontrol driven approaches. This perspective and modus operandi was reinforced further by the two 20th century World Wars and it continued through to the end of the Cold War, an era in which DRR/R was primarily seen as a question of civil defence with the underlying assumption that taking 'control' is the most suitable practise to deal with the 'chaos of disasters' (Dynes, 1994; Gilbert, 1995; Helsloot \& Ruitenberg, 2004; Quarantelli \& Dynes, 1977; Wolbers et al., 2016; Wolf \& Pfohl, 2014). This militaristic approach pervades many formal disaster operations to this day, notwithstanding the disaster governance emphasis that followed (Tierney, Bevc, \& Kuligowski, 2006; Wolbers et al., 2016). This situation is not only due to DRR/R's historical embeddedness in a military perspective, but also as result of concerns over Chemical, Biological, Radioactive and Nuclear-related issues as part of DRR/R (Strömberg, 2019).

Another issue arises in that FDG often separates and dilutes DRR/R activities among different institutions with their own rivalries, territorialism, and mandates, irrespective of overlaps and cooperation. To illustrate at a governmental level, governments such as the UK and US divide much of the responsibility for overseas disaster response, overseas DRR, domestic disaster response, and domestic DRR. The UN system has separate agencies for coordinating humanitarian affairs (Office for the Coordination of Humanitarian Affairs), disaster risk reduction (Office for Disaster Risk Reduction), development (United Nations Development Programme), and climate change (Framework Convention on Climate Change).

The critique of formal institutions as rigid, bureaucratic, and thus inflexible is common (Boin, Rhinard, \& Ekengren, 2014; Dynes \& Aguirre, 1979; Wachtendorf, 2000). Others contest this approach as being too simplistic (Bigley \& Roberts, 2001; Boersma, Comfort, Groenendaal, \& Wolbers, 2014), citing the capacity of command-and-control approaches to adapt to changing circumstances through, for instance, swapping predetermined roles or making choices as to which parts of the command structure are necessary and useful for any given situation. An example is the evolution of the Incident Command System and its application to hospitals (Bahrami, Ardalan, Nejati, Ostadtaghizadeh, \& Yari, 2020). Nonetheless, FDG has been characterised as "choices looking for problems, issues and feelings looking for decision situations in which they might be aired, solutions looking for issues to which they might be an answer, and decision makers looking for work" (Cohen, March, \& Olsen, 1972, p. 1). Yet governance which is entirely anarchist would run into its own problems through lack of systemisation, regulations, implementation, monitoring, and enforcement, leading to the high rate of disaster deaths seen in circumstances such as the 2010 Haiti earthquake (Mika, 2019) and the lack of a tsunami warning system across the Indian Ocean on 26 December 2004 compared to locations which had a local one, thereby saving lives (Gaillard et al., 2008). A balance between FDG and systems without formality would perhaps be needed for DRR/R.

\subsection{Defining Informality}

Considering DRR/R governance that is not formal, the supposed antonym 'informal' is the obvious choice, leading to IDG. The definition of 'informal' is suggested as being 'not formal,' but that would literally be 'non-formal.' 'Informal,' instead, is suggested as ad hoc or impromptu interactions between, and actions of, individuals and organisations, with the interactions being sudden, behind the scenes, casual, offhand, or unplanned (Kapucu, 2012; Wachtendorf, 2000; Zhuravsky, 2015). Others employ distinctions between state or recognised organisational formal DRR/R compared to civic DRR/R which, by default, becomes informal (Radcliffe, 2016; Sadri et al., 2018; Strömberg, 2019). Still others differentiate between attributes of institutionalised formal networks-which follow relatively set norms, ranges of actors, and rules of communication (but can also accommodate institutional informality) - and those of informal networks which are said to be ad hoc, although often based on repurposing previous networks to be fluid and ephemeral (Carrero et al., 2019; Chatfield \& Reddick, 2018; Meyer, 2017; Sadri et al., 2018). Few look into how informal DRR/R reinforces informal norms, their relationship with formal/enforced norms, and the potential of the former to 
change the latter and vice versa (Ng, 2016; Roasa, 2013; Toope, 2008; Tsai, 2006; Wolf \& Pfohl, 2014).

Overall, no satisfactory, cohesive, or operational definition is offered, partly because of the informality. When considering IDG, it is often implicitly or explicitly posited as the 'other,' 'parallel,' 'shadow,' or 'alternative' approach. That is, IDG is considered to be DRR/R governance which is not FDG, so it is defined in the context of what it is not, rather than what it is. Rather than a complementary approach to FDG, IDG is seen in dichotomous terms and it is easy to see why: governmental/civic, public/shadow (networks), and informal/formal straight away evoke the perception of opposites. Yet scholars studying in/formality have debated their characteristics and questioned the oversimplified generalisation of reality this dichotomy evokes (Toope, 2008). By definition, the formal-informal divide is a static conceptualisation, hiding the dynamics of what others propose is a continuum, with the depth or the existence of the formalinformal divide questioned (Sindzingre, 2006).

Ultimately, ephemeral concepts such as informality may defy the possibility of an overall or entirely accepted definition. At least initially, such definitions tend to be overly narrow for the sake of usefulness and they run the risks of oversimplification and promiscuous application. Are peoples' actions and norms that do not fit within the confines of the formal, necessarily informal? Or are they simply different? As Foweraker (2007, p. 407) states with respect to the treatment of informality in political science: "There are many forms of political behaviour, organisation and belief that cannot and should not be subsumed into the notion of informal rules." As an example from disaster science, this is apparent in indigenous peoples' DRR/R (e.g., Lambert \& Scott, 2019; Yumagulova et al., in press). Are indigenous actions that are not validated or mandated by the current government or systems informal by definition? Indigenous structures may be based on formal systems that have existed for far longer than the current 'recognised' DRR/R regimes. Other such examples include tribal or religious laws (e.g., the Albanian 'Kanun').

For studying IDG, here meaning informal DRR/R and its actors, we suggest embracing this seeming contradiction. Many IDG and FDG actors and efforts are to be found somewhere along a continuum as, for instance, formal actors act informally or vice versa. For instance, Alexander (2010) distinguishes between emergency response volunteers with different levels of spontaneity and organisation, indicating now the level of formality or informality with which they contribute can depend on their training, their level of integration with other involved institutions, and the volunteerism culture. Nonetheless, some intrinsic features of either informality or formality create a definite discontinuity between the two. Despite the regular or potential institutionalisation of initially informal acts, some are unlikely to ever make it into the formal sphere when their inherent features are fundamentally at odds with the inherent features of FDG; for example, legal avoidance strategies, such as the Japanese mafia providing aid after the 1995 Kobe earthquake (Horwich, 2000) and the Italian mafia being accused of both increasing and decreasing the earthquake vulnerability of houses (Massazza, Brewin, \& Joffe, 2019). Thus, IDG is not the opposite of FDG. Rather, it is a complementary, albeit underutilised and often little explained, part of the DRR/R governance spectrum.

\subsection{Reach: Informal DRR/R beyond Volunteerism}

Much of the current research on IDG takes a functionalist perspective, highlighting advantages in efficiency and efficacy over FDG. This perspective is a logical starting point and can be traced to the study of informal governance in political science in the 1980 s and 1990s which convincingly argued for integrating more flexibility into institutional settings to enable continuous learning, adaptation, and quick readjustment of processes in the face of perceived increasing uncertainty (De Burca, Keohane, \& Sabel, 2013). Such a functionalist rationale distracts from the agents of IDG and FDG, neglecting the deeper dimension of conflicting interests and power differentials within both IDG and FDG.

Yet IDG involves a variety of actors and agendas. Much of the functionalist critiques conceive of IDG actors as constrained in time (until FDG actors take charge), space (within the disaster's geographic constraints), and function/mandate (meeting immediate DRR/R needs). Unsurprisingly, IDG actors are thought of as temporarily filling in FDG gaps and are, ultimately, to be managed, including through ostensibly 'participatory approaches.' The reach of IDG actors and their efforts, though, often goes far beyond any perceived temporal, geographic, functional, and political boundaries.

Many disaster scenarios require IDG actors to take responsibility for their own DRR/R far beyond the immediate response phase, such as in situations in which FDG actors do not arrive at all; for instance, when a disaster has not been officially declared or FDG actors do not wish to get involved. The subsequent lack of attention and/or funds obtained by FDG actors impedes their activities. Then, it is up to IDG actors to take responsibility for the disaster-related needs, including the following recovery and development phases which can outlast any initial disaster response by years and even decades. These efforts can rarely be understood exclusively through terms like 'volunteerism' or 'self-help,' which themselves are very different, as they tend to emphasise limited engagement with respect to IDG actors' time and responsibility.

In fact, IDG may have potentially far-reaching societal and political implications. IDG does not happen in a vacuum but, put simply, may challenge old norms and, by extension, set new ones. Within this, there is a complex and complicated interplay between power, culture, and norms, in that existing FDG shapes the creation and development of IDG action. The reverse also occurs. IDG actors may equally set new norms against which (future) 
FDG actions will be pitched and bought into, or not (Tsai, 2006). These can be understood as being in between (i) Nye's (1990, p. 167) concept of 'soft power' from "intangible power resources such as culture, ideology, and institutions" and (ii) more classic or realist accounts of norm generation. That is, IDG has the potential to set norms - through negotiation within emerging hybrid relationships (e.g., beyond state-state, private-private), or through in/direct coercion-by establishing path dependencies through appealing alternatives that may seep into peoples' strategic cultures and, thus, exert influence over the acceptance, as well as the changing, of FDG's strategic culture (Levin, Cashore, Bernstein, \& Auld, 2012; Tsai, 2006; Wolf \& Pfohl, 2014).

In this way, IDG also constitutes the environment within which FDG is accepted, enabled, constrained, or rejected. In the framework by Helmke and Levitsky (2004, 2006), FDG and IDG may thus either converge (by being complementary or substitutive) or diverge (resulting in behaviour which is competing or which tolerates differences without approving or engaging with them). FDG is embedded within shared expectations which create the 'rules of the game,' dictating the effectiveness and stability of the current framework. Governance, through setting standards, blurs classic dividing lines between the public and the private, and between the national and the non-national.

In other cases, IDG may eschew any formal engagement. In theory, partially thanks to the apposite focus on vulnerabilities as the causative factors of disasters (Hewitt, 1983; Lewis, 1999; Wisner et al., 2004), disaster science has recently paid more attention to those ignored or bypassed by FDG. But what about turning this around to ask: What does it mean to ignore FDG? The implicit demand of FDG is to pay attention to formal approaches, processes, and institutions. 'Ignoring' - that is, the lack of attention to FDG institutions-may constitute indirect or direct contention with FDG's practices and, sometimes, with FDG as a system per se. 'Governance beyond/without government' (Ng, 2016; Peters \& Pierre, 1998; Rosenau \& Czempiel, 1992) becomes possible and, in order to achieve civic goals, desired for establishing new alliances. These informal or grassroot movements are not only about shifting identities but, similar to classical politics, remain deeply political whether in standard 'us vs. them' terms or as 'agonistic pluralism,' where the other's legitimacy is recognised yet not reconciled (Mouffe, 2013).

\subsection{The Dark Side(s) of IDG}

IDG is subject to many of the 'dark sides' of DRR/R governance in general. Any form of governance can produce unintended path dependencies or adverse impacts, meaning that caution is inevitably warranted. This section presents some of these negative aspects as a means of balancing the ostensibly positive nature of IDG referred to thus far, especially when considering literature on community-based or participatory DRR/R. In the case of IDG, presenting these drawbacks is particularly important since the lack of focused attention that the topic has received to date may not have resulted in the same counter-measures as for FDG. Like FDG, informality has a clear potential to be less positive and potentially cause harm, with lessons drawn from FDG and related formal mechanisms (Cooke \& Kothari, 2001; Hickey \& Mohan, 2005; Ide, 2020). Much relates to imbalanced distributions of power inherent in any system, unregulated or otherwise (Pretty, 1995), but informality produces challenges in that accountability, monitoring, and enforcement are not necessarily expected, as they might be in formal systems.

IDG, may circumvent-intentionally or unintentionally-institutional and governmental policies and strategies. While in some cases such informal action may be acknowledged as helpful and be tacitly or explicitly permitted, in other cases, informal action may be perceived as challenging formal organisations and structures, including governments, leading to tensions and/or putting informal actors at direct risk of censorship, punishment, or persecution. Conversely, similar aspects may be at play with respect to vertical governance relations when stronger parties divert the attention of formal institutions. Bradford (1998) shows how efforts by the Government of Ontario to improve occupational health and safety policies were undermined by advantaged private sector representatives who were able to gain access to senior officials through informal channels. Thus, while governments can acknowledge their limitations and allow or actively support IDG, intra-community power relations can also hinder IDG when powerful locals play active roles in the formal structures. As shown empirically for Malawi, even when FDG governmental mechanisms are weak, post-disaster work typically needs them anyway (Hendriks \& Boersma, 2019). Bypassing government for disaster governance, either IDG or FDG, might not always be possible or desirable.

A related important dimension is conflict potential, extending not only to the access to resources for disaster governance, but also to resource control. In informal situations, water, electricity, or similar 'mafias' appear (Mahadevia, 2015) which thus have the potential to provide aid to the disaster-affected population at exorbitant prices, or prioritising/restricting the access of certain groups, along with price gouging for basic supplies and services (Noy, 2018). Tendler (2002) refers to these anti-development dynamics as 'the devil's deal' that perpetuates dependence rather than healthy, participatory governance and political empowerment.

Meanwhile, informality may sometimes be encouraged by FDG actors because it assists them in reaching their own goals. In traditional formal institutions, the presence of (unsanctioned) informal set-ups does not often grant weaker actors opportunities to vocalise or pursue their preferences, leaving powerful actors freer to dictate actions on the basis of their presumed su- 
perior agenda-setting power and bargaining leverage. Personalities can make a difference, such as the personal friendship between the Greek and Turkish foreign ministers in 1999 which assisted those two countries in continuing to pursue rapprochement in the wake of post-earthquake mutual aid, and the backlash to it, after earthquakes hit each country in August-September 1999 (Ker-Lindsay, 2000). Powerful players, even ministers within the formal institutions of elected government, can have strong incentives to steer institutional design and actions based on, and towards, higher levels of informality, such as friendship, particularly in situations where their preferences and power are strong.

Finally, despite the resourcefulness, creativity, and flexibility often inherent in informal networks-even without being dominated or taken over by powerful players-resources, skills, transparency, and accountability can hamper effectiveness as a result of disorganisation, inadequate training, and being tasked with responsibilities without concomitant resources (Meyer, 2017). People implementing DRR/R can face the dilemma of conflicting group loyalties when they find themselves caught between obligations to family, other groups they belong to or identify with, and emerging groups. Killian (1952) calls this situation the conflict between ordinarily non-conflicting multiple group loyalties and it can impede IDG by making its positive aspects appear to entail disloyal and intractable choices.

\section{Svalbard Norway as an IDG Case Study}

Developing IDG in theory is a useful baseline but exploring it in practice is also helpful. A case study already known for its informality in numerous areas of society, including health and safety, assists in examining exactly what does or might happen with IDG in reality. Settlements with small populations, such as on isolated islands, are frequently touted and complimented for their tight social networks and informal governance, with the positives and negatives analysed (Baldacchino, 2018). Grydeh $\varnothing$ (2014) highlights the Svalbard archipelago as a key global example.

Situated in the high Arctic, Svalbard belongs to Norway by the Svalbard Treaty (1920) that governs it, granting resource extraction and residence rights to citizens of signatory countries. $80 \%$ of the population of 2,500-3,000 lives in the capital Longyearbyen, with the mainly Russian Barentsburg being the territory's second largest settlement. Norway and Russia are the only countries that have maintained a reasonably continual presence on Svalbard since the archipelago was known to be discovered. Svalbard's inhabited areas are mostly in coastal lowlands with risks from local sources being highlighted as aircraft and snowmobile crashes, polar bear attacks, avalanches and other slides, floods, droughts, and disease.

Svalbard epidemics were considered long before the 2020 Covid-19 outbreak. Examples are tapeworms, ra- bies, and the re-emergence of a (potentially mutated) H1N1 virus which previously killed miners on Svalbard during the 1918 Spanish flu pandemic and which remained in corpses' tissues that failed to decompose in Svalbard's permafrost (Davis et al., 2000; Fuglei et al., 2008; MacDonald et al., 2011). DRR/R discussions for Svalbard's diseases emphasise the spectre of a cruise ship outbreak, for which norovirus is notable, especially since many vessels carry more people than live around Svalbard (Klein, 2010).

Svalbard's healthcare facilities and services are limited, with Longyearbyen's small hospital and Barentsburg's clinic being the main options. A large influx of ill patients and cases with major complications would tax Svalbard's healthcare services, especially in cases such as Covid-19 with a high number of infectious people requiring isolation. Awareness of this situation around Svalbard is high, partially due to the cruise ships reaching the islands on a near-monthly basis. The 2020 Covid-19 outbreak spreading on cruise ships around the world, and the fact that the ships often dock in various ports with passengers disembarking before an outbreak is identified, demonstrates the catastrophic consequences which could impact Svalbard's health systems.

With this knowledge, Svalbard swiftly enacted Covid-19-related precautions, particularly protocols for communication and patient evacuation to the nearest mainland medical centre, Troms $\varnothing$, Norway. As travel restrictions became evident, Svalbard's Governor soon announced measures which banned visitors from nonNordic countries, quarantined tourists already there and flew them to Oslo, and forced a seven-day self-isolated period for those arriving in Svalbard's other communities.

Nonetheless, locals described the initial official response as patchy, confusing, and slow (personal communication with a community member, 2020; Sabbatini, 2020a). As in other situations, on Svalbard or elsewhere, the lack of focus on DRR and preparedness means that disaster response plans are overemphasised which, in turn, are often based on past experiences. Thus, disaster scenarios that fall outside of past experiences tend to pose significant challenges. This was previously demonstrated in Svalbard's 2015 and 2017 Longyearbyen avalanches, the former of which destroyed eleven houses, killed two people, and injured many more. Despite official reports warning for years of Longyearbyen's avalanche risks (NGI, 1991, 1992, 2001), "no avalanche warning was in operation" (Jaedicke, Hestnes, Bakkehøi, Mørk, \& Brattlien, 2016, p. 379). Moreover, previous experiences with (fatal) avalanches on Svalbard predominately referred to backcountry avalanches which became the main focus of official DRR/R efforts.

Thus, both in the avalanches and during the 2020 Covid-19 outbreak, IDG as outlined in Sections 1 and 2 appeared, with residents unofficially stepping in. In the 2015 avalanche, over 150 citizens participated in the search-and-rescue efforts, many of whom had been informed of the disaster through an informal local mes- 
senger group and then arrived on scene prior to official first responders helping, illustrating the noted IDG concepts of volunteerism, self-organisation, convergence, and zero-order responders. They rescued and evacuated people and then provided officials with valuable knowledge of homes' physical layout, thereby facilitating the finding of those trapped (Indreiten \& Svarstad, 2016), exactly as described in early research on aspects of informality in disasters (Form \& Nosow, 1958).

Similarly, as FDG actors in Svalbard, the rest of Norway, and elsewhere were caught somewhat off-guard regarding the Covid-19 pandemic, local Svalbard residents took initiatives to compensate for the lack of essential formal disaster services. Using informal channels such as local Facebook and WhatsApp groups, thereby governing by bypassing governments and formal systems as described in IDG's theory, local residents offered services for those self-isolated at home, including shopping, deliveries, free psychosocial support, meditation, and yoga, along with free babysitting for those who could not work from home (Sabbatini, 2020b). As Sabbatini (2020a, 2020b) indicates, the information was also reported and disseminated through a self-organised informal system, namely the self-published icepeople.net, as per the communication structures theorised in IDG. Grassroots advocates in Longyearbyen actively elevated discussions of compensation packages to the political level to benefit Svalbard's immigrant workers who were laid off and left in a situation of little-to-no social and legal support (personal communication with a community member, 2020). Meanwhile, guides and other tourism personnel bypassed formal organisations to release their own statements, irrespective of governmental guidelines, regarding their strategies for making it through the crisis and moving forward including through support from informal networks.

Such informal activities show the need for FDG actors, including emergency responders, to go beyond recognising ordinary citizens as merely participants to be invited on FDG actors' terms. Instead, as per the theory, informal actors need to be accepted and leveraged as key partners identifying and filling in important gaps, thereby also relieving pressure on FDG actors while raising important issues which FDG might not have considered. Equally, recognising partners requires acknowledging each's limitations and any problematic agendas, especially to admit, avoid, and overcome the dark sides of IDG (Section 2.4). In the case of Svalbard and Covid-19, the aforementioned delivery services could potentially enact price gouging or other behaviour reminiscent of the 'devil's deal' from Tendler (2002). Even the free psychosocial support generously offered raised questions regarding access, accountability, and 'care for the carers.'

By providing an enabling environment before and during disasters that overstretch FDG resources, such as the Covid-19 pandemic in an isolated location with limited healthcare resources, IDG could and should be meaningfully harnessed. By careful integration and complementarity with FDG actors, all expertise could be fully used, rather than IDG's dark sides dominating or IDG's actors being managed top-down or viewed as panicking 'victims' and/or bothersome problems to be 'managed away' (Clarke, 2002; Ogie \& Pradhan, 2019). As spontaneously happened around Svalbard for the avalanches and Covid-19, which is typical of the governance culture of the settlements (e.g., the local government using local social media groups), Gaventa (2004, p. 21) describes this task as no less than "the construction of new relationships between ordinary people and the institutionsespecially those of government-which affect their lives" which constitutes a "key challenge for the 21st century."

\section{Conclusion: Towards IDG}

This article reviewed IDG, indicated the positive and negative aspects, applied it to a specific case study historically and contemporarily, and suggested gaps which are yet to be filled. Current (academic) reflection on IDGand its preoccupation with either interorganisational informality or narrow concepts such as first/zero-order responders, self-organisation, convergence, emergence, and volunteerism - is insufficient to account for the major role of IDG actors and their activities. The study of informality itself is highly complex and can produce ostensible contradictions such as formalising informality and seeking informal aspects within formality.

As with disasters themselves, the lack of definitional consensus and the power connected with who decides on what constitutes a 'disaster,' informal actors have long suffered from a lack of voice due, in part, to an inherent absence of a basic conceptualisation of the term. Thus, we suggest the term IDG to indicate the increased role that informality has vis-à-vis what is currently acknowledged. In drawing on the theoretical and empirical discussion in this article, including the case study's lessons, the focus for recommendations is on high-level conceptual aspects to ensure an adequate academic grounding in how IDG studies and actions develop while aiming to provide baselines for overcoming IDG's dark sides.

First, informality is not a new concept for DRR/R, but IDG presents a novel framework for it, so it should be used to understand informality in DRR/R and how to best recognise and use it. Second, words matter and the labelling, including translations beyond English, need to be considered carefully, with the tenets taken seriously and applied in practice. A unified framework with a clear name, i.e., IDG, supports this approach and ensures an appropriate balance with the extensive work on and acceptance of FDG. Third, accepting and applying IDG completes a much fuller DRR/R governance picture. By extension, an IDG-FDG dialogue may bring about the changes necessary for disaster governance to become more efficient and effective, a stated need and goal within much DRR/R research and practice. IDG contributes to resolving the long-term debate in DRR/R on transparency, methods, legitimacy, and structures of current disaster governance norms and means. 
Overarchingly, the 'informality' in IDG refers to informal actors and informal actions in $D R R / R$, broadly understood as individuals or groups (any actors) acting voluntarily, in an impromptu or unplanned manner, or because they feel they must, yet without having been formally mandated and without any formal, systematic, or necessarily structured fashion. We emphasise the notion of 'framework' to avoid presenting IDG as merely a new phrase for an old concept (or multitudes thereof). Informal DRR/R does not need new names but rather a framework to be filled with both long-standing and new literature connecting theory and practice. Furthermore, IDG needs to be studied comprehensively and critically to avoid overly optimistic accounts and to go beyond the simplistic rhetoric of formal vs. informal, of informal as non-formal, or of top-down vs. bottom-up for disaster governance.

\section{Acknowledgments}

This research was supported by the Research Council of Norway, Project 286527/H30 "Norway-Russia Disaster Diplomacy in the High North and Arctic."

\section{References}

Alexander, D. (2010). The voluntary sector in emergency response and civil protection: Review and recommendations. International Journal of Emergency Management, 7(2), 151-166.

Bahrami, P., Ardalan, A., Nejati, A., Ostadtaghizadeh, A., \& Yari, A. (2020). Factors affecting the effectiveness of hospital incident command system: Findings from a systematic review. Bulletin of Emergency and Trauma, 8(2) 62-76.

Baldacchino, G. (Ed.). (2018). The Routledge international handbook of island studies: A world of islands. Abingdon: Routledge.

Barenstein, J. E. D., \& Trachsel, S. (2012). The role of informal governance in post-disaster reconstruction and its impact on elderly people's social security in coastal Tamil Nadu. In J. E. D. Barenstein \& E. Leemann (Eds.), Post-disaster reconstruction and change: Communities' perspectives (pp. 157-176). Boca Raton, FL: CRC Press.

Bigley, G. A., \& Roberts, K. H. (2001). The incident command system: High-reliability organizing for complex and volatile task environments. Academy of Management Journal, 44(6), 1281-1299.

Boersma, F. K., Comfort, L. K., Groenendaal, J., \& Wolbers, J. J. (2014). Editorial: Incident command systems: A dynamic tension among goals, rules and practice. Journal of Contingencies and Crisis Management, 22(1), 1-4.

Boersma, F. K., Ferguson, J., Groenewegen, P., Mulder, F., Schmidt, A., \& Wolbers, J. (2019). Platform governance of self-organized initiatives in response to disasters. In J. Koppenjan, P. M. Karré, \& K. Ter- meer (Eds.), Smart hybridity: Potentials and challenges of new governance arrangements (pp. 31-42) The Hague: Eleven International Publishing.

Boin, A. (2009). The new world of crises and crisis management: Implications for policymaking and research. Review of Policy Research, 26(4), 367-377.

Boin, A., Rhinard, M., \& Ekengren, M. (2014). Managing transboundary crises: The emergence of European Union capacity. Journal of Contingencies and Crisis Management, 22(3), 131-142.

Bradford, N. (1998). Prospects for associative governance: Lessons from Ontario, Canada. Politics \& Society, 26(4), 539-573.

Briones, F., Vachon, R., \& Glantz, M. (2019). Local responses to disasters: Recent lessons from zero-order responders. Disaster Prevention and Management, 28(1), 119-125.

Carrero, R., Acuto, M., Tzachor, A., Subedi, N., Campbell, B., \& To, L. S. (2019). Tacit networks, crucial care: Informal networks and disaster response in Nepal's 2015 Gorkha earthquake. Urban Studies, 56(3), 561-577.

Chatfield, A. T., \& Reddick, C. G. (2018). All hands on deck to tweet \#sandy: Networked governance of citizen coproduction in turbulent times. Government Information Quarterly, 35(2), 259-272.

Clarke, L. (2002). Panic: Myth or reality? Contexts, 1(3), 21-26.

Cohen, M. D., March, J. G., \& Olsen, J. P. (1972). A garbage can model of organizational choice. Administrative Science Quarterly, 17(1), 1-25.

Cooke, B., \& Kothari, U. (Eds.). (2001). Participation: The new tyranny? New York, NY: Zed Books.

Cuny, F. C. (1994). Disasters and development. Dallas, TX: Intertect Press.

Davis, J. L., Heginbottom, J. A., Annan, A. P., Daniels, R. S., Berdal, B. P., Bergan, T., . . . Smith, C. R. (2000). Ground penetrating radar surveys to locate 1918 Spanish flu victims in permafrost. Journal of Forensic Sciences, 45(1), 68-76.

De Burca, G., Keohane, R. O., \& Sabel, C. (2013). New modes of pluralist global governance. International Law and Politics, 45(3), 723-781.

Dynes, R. R. (1994). Community emergency planning: False assumptions and inappropriate analogies. International Journal of Mass Emergencies and Disasters, 12(2), 141-158.

Dynes, R. R., \& Aguirre, B. E. (1979). Organizational adaptation to crises: Mechanisms of coordination and structural change. Disasters 3(1), 71-74.

Edwards, F. L. (2009). Effective disaster response in cross border events. Journal of Contingencies and Crisis Management, 17(4), 255-265.

Fawaz, M. (2017). Planning and the refugee crisis: Informality as a framework of analysis and reflection. Planning Theory, 16(1), 99-115.

Form, W. H., \& Nosow, S. (Eds.). (1958). Community in disaster. New York, NY: Harper. 
Foweraker, J. (2007). Gretchen Helmke and Steven Levitsky (eds.), Informal institutions and democracy: Lessons from Latin America (Baltimore, MD: Johns Hopkins University Press, 2006), pp. viii+351, f43.50, 16.50 pb. Journal of Latin American Studies, 39(2), 406--407.https://doi.org/10.1017/ S0022216X07002520

Fritz, C. E., \& Mathewson, J. H. (1957). Convergence behaviour in disasters: A problem in social control (Disaster Study No. 9). Washington, DC: National Academy of Sciences.

Fuglei, E., Stien, A., Yoccoz, N. G., Ims, R. A., Eide, N. E., Prestrud, P., . . O Oksanen, A. (2008). Spatial distribution of Echinococcus multilocularis, Svalbard, Norway. Emerging Infectious Diseases, 14(1), 73-75.

Gaillard, J.-C., Clavé, E., Vibert, O., Azhari, Dedi, Denain, J. C., .. Setiawan, R. (2008). Ethnic groups' response to the 26 December 2004 earthquake and tsunami in Aceh, Indonesia. Natural Hazards, 47(1), 17-38.

Gaventa, J. (2004). Towards participatory local governance: Assessing the transformative possibilities. In S. Hickey \& G. Mohan (Eds.), Participation: From tyranny to transformation (pp. 24-41). London: Zed Books.

Gilbert, C. (1995). Studying disaster: A review of the main conceptual tools. International Journal of Mass Emergencies and Disasters, 13(3), 231-240.

Grove, K. (2014). Biopolitics and adaptation: Governing socio-ecological contingency through climate change and disaster studies. Geography Compass, 8(3), 198-210.

Grydeh $\varnothing$, A. (2014). Informal diplomacy in Norway's Svalbard policy: The intersection of local community development and Arctic international relations. Global Change, Peace \& Security, 26(1), 41-54.

Helmke, G., \& Levitsky, S. (2004). Informal institutions and comparative politics: A research agenda. Perspectives on Politics, 2(4), 725-740.

Helmke, G., \& Levitsky, S. (2006). Introduction. In G. Helmke \& S. Levitsky (Eds.), Informal institutions and democracy: Lessons from Latin America (pp. 1-30). Baltimore, MD: The John Hopkins University Press.

Helsloot, I., \& Ruitenberg, A. (2004). Citizen response to disasters: A survey of literature and some practical implications. Journal of Contingencies and Crisis Management, 12(3), 98-111.

Hendriks, T. D., \& Boersma, F. K. (2019). Bringing the state back in to humanitarian crises response: Disaster governance and challenging collaborations in the 2015 Malawi flood response. International Journal of Disaster Risk Reduction, 40. https://doi.org/10.1016/ j.ijdrr.2019.101262

Hewitt, K. (Ed.). (1983). Interpretations of calamity from the viewpoint of human ecology. London: Allen \& Unwin.

Hickey, S., \& Mohan, G. (Eds.). (2005). Participation: From tyranny to transformation? Exploring new approaches to participation in development. New York:
Zed Books.

Horwich, G. (2000). Economic lessons of the Kobe earthquake. Economic Development and Cultural Change, 48(3), 521-542.

Ide, T. (2020). The dark side of environmental peacebuilding. World Development, 127. https://doi.org/ 10.1016/j.worlddev.2019.104777

Indreiten, M., \& Svarstad, C. (2016). The Longyearbyen fatal avalanche accident 19th December 2015, Svalbard: Lessons learned from avalanche rescue inside a settlement. In Proceedings of the international snow science workshop (pp. 356-362). Breckenridge, CO: International Snow Science Workshop.

Jaedicke, C., Hestnes, E., Bakkehøi, S., Mørk, T., \& Brattlien, K. (2016). Forecasting the fatal Longyearbyen avalanche. Possibilities and challenges. In Proceedings of the international snow science workshop (pp. 379-382). Breckenridge, CO: International Snow Science Workshop.

Kapucu, N. (2012). Disaster and emergency management systems in urban areas. Cities, 29, 41-49.

Ker-Lindsay, J. (2000). Greek-Turkish rapprochement: The impact of "disaster diplomacy"? Cambridge Review of International Affairs, 14(1), 215-232.

Killian, L. M. (1952). The significance of multiple-group membership in disaster. American Journal of Sociology, 57(4), 309-314.

Kirschenbaum, A. (2004). Chaos organization and disaster management. New York, NY and Basel: Marcel Dekker, Inc.

Klein, R. A. (2010). Cruises and bruises: Safety, security and social issues on polar cruises. In M. Lück, P. T. Maher, \& E. J. Stewart (Eds.), Cruise tourism in polar regions: Promoting environmental and social sustainability? (pp. 55-73). London: Earthscan.

Lagadec, P. (1997). Learning processes for crisis management in complex organizations. Journal of Contingencies and Crisis Management, 5(1), 24-31.

Lambert, S. J., \& Scott, J. C. (2019). International disaster risk reduction strategies and indigenous peoples. The International Indigenous Policy Journal, 10(2). https://doi.org/10.18584/iipj.2019.10.2.2

Lavell, A., \& Maskrey, A. (2014). The future of disaster risk management. Environmental Hazards, 13(4), 267-280.

Levin, K., Cashore, B., Bernstein, S., \& Auld, G. (2012). Overcoming the tragedy of super wicked problems: Constraining our future selves to ameliorate global climate change. Policy Sciences, 45(2), 123-152.

Lewis, J. (1999). Development in disaster-prone places: Studies of vulnerability. London: Intermediate Technology Publications.

MacDonald, E., Handeland, K., Blystad, H., Bergsaker, M., Fladberg, M., Gjerset, B., . . . Tveiten, O. (2011). Public health implications of an outbreak of rabies in arctic foxes and reindeer in the Svalbard archipelago, Norway, September 2011. Euro Surveillance, 16(40). https://doi.org/10.2807/ese.16.40.19985-en 
Mahadevia, D. (2015, September 29). Limits of informality [Video file]. Retrieved from https://urbangrowth. usc.edu/2015-fall-semester-seminars/september29-limits-of-informality

Marchezini, V. (2015). The biopolitics of disaster: Power, discourses, and practices. Human Organization, 74(4), 362-371.

Maskrey, A. (2011). Revisiting community-based disaster risk management. Environmental Hazards, 10(1), 42-52.

Massazza, A., Brewin, C. R., \& Joffe, H. (2019). The nature of "natural disasters": Survivors' explanations of earthquake damage. International Journal of Disaster Risk Science, 10, 293-305.

McFarlane, C. (2012). Rethinking informality: Politics, crisis, and the city. Planning Theory \& Practice, 13(1), 89-108.

Meyer, M. (2017). The family's burden. In E. C. Jones \& A. J. Faas (Eds.), Social network analysis of disaster response, recovery, and adaptation (pp. 127-141). Oxford: Elsevier.

Mika, K. (2019). Disasters, vulnerability, and narratives: Writing Haiti's futures. London: Routledge.

Mouffe, C. (2013). Agonistics: Thinking the world politically (1st ed.). London and Brooklyn, NY: Verso.

$\mathrm{Ng}$, S. (2016). Governance beyond the government: Responding to a reactionary flood governance regime in Ayutthaya, Thailand. Habitat International, 52, 11-19.

NGI. (1991). Vurdering av tiltak mot snøskred, sørpeskred og drivsnø $i$ Longyearbyen [Assessment of measures against avalanches, slush slides, and drifting snow in Longyearbyen] (No. 904025-1). Oslo: Norges Geotekniske Institutt.

NGI. (1992). Lia Longyearbyen: Vurdering av snøskredfare og tiltak for å hindre ulykker ved veg 226-230 [Assessment of avalanche hazard and measures to prevent road crashes] (No. 904025-2). Oslo: Norges Geotekniske Institutt.

NGI. (2001). Vannledningsdalen-Gruvedalen, Longyearbyen: Skredfarevurdering [VannledningsdalenGruvedalen, Longyearbyen: Landslide hazard assessment] (No. 20011167-1). Oslo: Norges Geotekniske Institutt.

Noy, I. (2018). The ethical content of the economic analysis of disasters: Price gouging and post-disaster recovery. In D. P. O'Mathúna, V. Dranseika, \& B. Gordijn (Eds.), Disasters: Core concepts and ethical theories (pp. 55-68). Cham: Springer.

Nye, J. S., Jr. (1990). Soft power. Foreign Policy, 80, 153-171.

Ogie, R. I., \& Pradhan, B. (2019). Natural hazards and social vulnerability of place: The strength-based approach applied to Wollongong, Australia. International Journal of Disaster Risk Science, 10, 404-420.

Parthasarathy, D. (2015). Informality, resilience, and the political implications of disaster governance. Pacific Affairs, 88(3), 551-575.

Perrow, C. (2011). The next catastrophe: Reducing our vulnerabilities to natural, industrial, and terrorist disasters. Princeton, NJ: Princeton University Press.

Peters, B. G., \& Pierre, J. (1998). Governance without government? Rethinking public administration. Journal of Public Administration Research and Theory, 8(2), 223-243.

Pretty, J. N. (1995). Participatory learning for sustainable agriculture. World Development, 23(8), 1247-1263.

Quarantelli, E. L., \& Dynes, R. R. (1977). Response to social crisis and disaster. Annual Review of Sociology, 3(1), 23-49.

Quarantelli, E. L., Lagadec, P., \& Boin, A. (2007). A heuristic approach to future disasters and crises: New, old, and in-between types. In H. Rodríguez, E. L. Quarantelli, \& R. R. Dynes (Eds.), Handbook of disaster research (pp. 16-41). New York, NY: Springer.

Radcliffe, S. A. (2016). Civil society: Management, mismanagement and informal governance. In J. Grugel \& D. Hammett (Eds.), The Palgrave handbook of international development (pp. 227-242). London: Palgrave Macmillan.

Roasa, D. (2013, April 29). The D.I.Y. disaster plan: How informal networks battled Bangkok's worst flood: The Informal city dialogues. Next City. Retrieved from https://nextcity.org/informalcity/entry/bangkokfloods-the-diy-disaster-plan

Robin, E., Chazal, C., Acuto, M., \& Carrero, R. (2019). (Un)learning the city through crisis: Lessons from Cape Town. Oxford Review of Education, 45(2), 242-257.

Rose, J., \& Chmutina, K. (in press). Developing disaster risk reduction skills among informal construction workers in Nepal. Disasters.

Rosenau, J. N., \& Czempiel, E.-O. (Eds.). (1992). Governance without government: Order and change in world politics. Cambridge: Cambridge University Press.

Sabbatini, M. (2020a, March 13). Coronavirus/overview update for Friday, Mar. 13: Non-Nordic visitors banned from Svalbard; North Pole season cancelled, governor's office closes to visitors, locals offer shopping/babysitting. Icepeople.net. Retrieved from http://icepeople.net/2020/03/13/coronavirusoverview-update-for-friday-feb-13-north-poleseason-cancelled-governors-office-closes-tovisitors-ban-on-arriving-tourists-sought-localsoffer-shoppingbabysitting

Sabbatini, M. (2020b, March 19). Coronavirus updates for Svalbard for Thursday: Radisson closing this weekend, free psychosocial counselling offered, machinery to block trails to Svea and more. Icepeople.net. Retrieved from http://icepeople.net/ 2020/03/19/coronavirus-updates-for-svalbard-forthursday-radisson-closing-this-weekend-privateremote-snowmobile-salvage-offered-machinery-toblock-trails-to-svea-and-more

Sadri, A. M., Ukkusuri, S. V., Lee, S., Clawson, R., Aldrich, D., Nelson, M. S., . . Kelly, D. (2018). The role of 
social capital, personal networks, and emergency responders in post-disaster recovery and resilience: $\mathrm{A}$ study of rural communities in Indiana. Natural Hazards, 90(3), 1377-1406.

Sindzingre, A. (2006). The relevance of the concepts of formality and informality: A theoretical appraisal. In B. Guha-Khasnobis, R. Kanbur, \& E. Ostrom (Eds.), Linking the formal and informal economy: Concepts and policies (pp. 58-73). Oxford: Oxford University Press.

Stallings, R. A., \& Quarantelli, E. L. (1985). Emergent citizen groups and emergency management. Public $\mathrm{Ad}$ ministration Review, 45, 93-100.

Strömberg, D. (2019). The role of the military: A study in how civil-military cooperation is formed during CBRN incidents (Master dissertation). Umeå: Umeå University.

Svalbard Treaty. (1920). Treaty between Norway, The United States of America, Denmark, France, Italy, Japan, the Netherlands, Great Britain and Ireland and the British overseas Dominions and Sweden Concerning Spitsbergen Signed in Paris 9 February 1920. Paris: Svalbard Treaty.

Tendler, J. (2002). Small firms, the informal sector, and the devil's deal. IDS Bulletin, 33(3), 1-15.

Tierney, K., Bevc, C., \& Kuligowski, E. (2006). Metaphors matter: Disaster myths, media frames, and their consequences in hurricane Katrina. The Annals of the American Academy of Political and Social Science, 604, 57-81.

Toope, S. J. (2008). Formality and informality. In D. Bodansky, J. Brunnée, \& E. Hey (Eds.), The Oxford handbook of international environmental law (pp. 107-124). Oxford: Oxford University Press.
Tsai, K. S. (2006). Adaptive informal institutions and endogenous institutional change in china. World Politics, 59(1), 116-141.

Wachtendorf, T. (2000). When disasters defy borders: What we can learn from the Red River flood about transnational disasters. Australian Journal of Emergency Management, 15(3), 36-41.

Whittaker, J., McLennan, B., \& Handmer, J. (2015). A review of informal volunteerism in emergencies and disasters: Definition, opportunities and challenges. International Journal of Disaster Risk Reduction, 13, 358-368.

Wisner, B., Blaikie, P., Cannon, T., \& Davis, I. (2004). At risk: Natural hazards, people's vulnerability and disasters (2nd ed.). London: Routledge.

Wolbers, J., Ferguson, J., Groenewegen, P., Mulder, F., \& Boersma, K. (2016). Two faces of disaster response: Transcending the dichotomy of control and collaboration during the Nepal earthquake relief operation. International Journal of Mass Emergencies and Disasters, 34(3), 419-438.

Wolf, F., \& Pfohl, T. (2014). Protecting the population in a multilevel system: Horizontal and vertical informal governance patterns in Germany. Zeitschrift Für Vergleichende Politikwissenschaft, 8(1), 259-285.

Yumagulova, L., Phibbs, S., Kenney, C. M., Yellow Old Woman-Munro, D., Christianson, A. C., McGee, T. K., \& Whitehair, R. (in press). The role of disaster volunteering in Indigenous communities. Environmental Hazards.

Zhuravsky, L. (2015). Crisis leadership in an acute clinical setting: Christchurch hospital, New Zealand ICU experience following the February 2011 earthquake. Prehospital and Disaster Medicine, 30(2), 131-136.

\section{About the Authors}
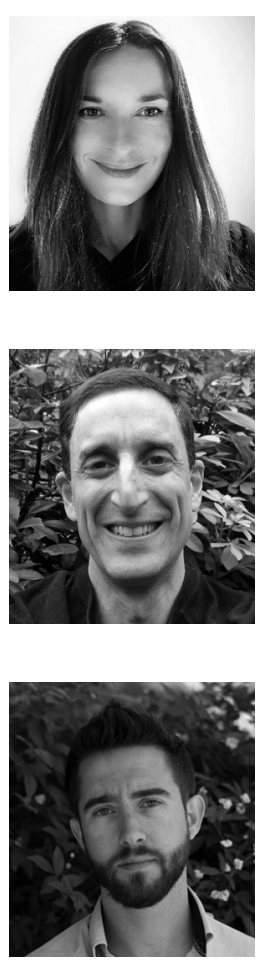

Patrizia Isabelle Duda is a PhD Researcher at UCL IRDR where she studies informal disaster networks in the Arctic and Caribbean. She is affiliated with the University of Adger, Norway, through the collaborative NORRUSS research project, focusing on Norway-Russia relations and disaster diplomacy on Svalbard. Before shifting to disasters as a practitioner and researcher, Patrizia spent 15 years working and conducting academic research in the fields of business strategy and international security.

Ilan Kelman is Professor of Disasters and Health at University College London, England, and a Professor II at the University of Agder, Kristiansand, Norway. His overall research interest is linking disasters and health, such as by integrating climate change, migration, and diplomacy. into disaster research and health research. His main locations of interest are islands, archipelagos, the Arctic, and the Antarctic. His personal website is http://www.ilankelman.org and Twitter/Instagram @ILANKELMAN.

Navonel Glick is an award-winning non-profit Leader with 12 years of experience in disaster risk reduction and response, combining extensive field experience with executive and strategic leadership. As former Co-CEO of IsraAID, he has overseen disaster programmes in 43 countries, and notably led missions to the Philippines (2013 Typhoon Haiyan), Sierra Leone (2014 Ebola outbreak), and Iraq (2014 rise of ISIS). Navonel was awarded a Muhammad Ali Humanitarian Core Principles Award (2016) and made Forbes Magazine's '30 Under 30’ list. 